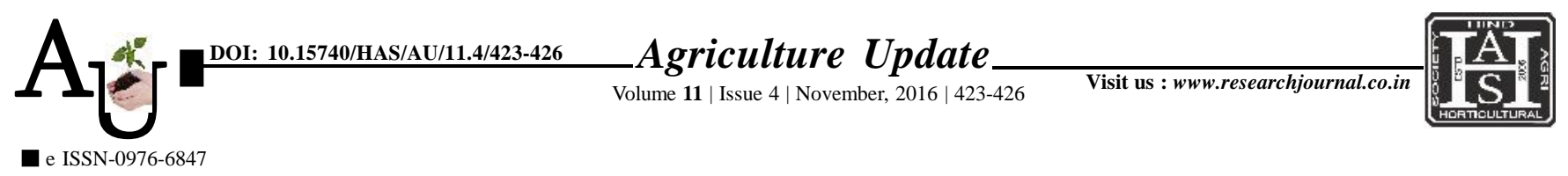

\title{
Research Aвтісle: Potato production through telecounselling mode of extension education
}

\author{
R.A. SINGH, AMAR SINGH, DHARMENDRA YADAV, JITENDRA SINGH AND \\ S.B. PAL
}

Article Chronicle:

Received :

09.08.2016;

Revised :

02.10.2016;

Accepted :

18.10.2016

KeY WoRDS:

Dissemination,

Effective media, Mass media, New horizon, Telecouselling mode
SUMMARY : There are several modes are available for teaching to the farmers through distance training system, out of which telecast of video programme, broadcast of audio programmes, telecounselling etc. are eco-friendly modes, solving the farmers problems. The telecounselling is a ecofriendly and easy system of distance training, which is available in rural area in the form of mobiles and landline. The experiment on telecounselling for improvement of potato yield was tried in the villages Bhawanipur and Daipur of district Kannauj and Rajpura, Baghauli, Jasharau and Shaidpur of district Mainpuri for the first time. The soil of experimental site was sandy loam with poor fertility. There is certain drawback in the cultivation of potato. The farmers are not using the recommended agronomic practices, resulting in, the low yield obtained from potato. The farm families of potato growers were linked with C.S.Azad University of Agriculture and Technology, Kanpur and KVK, Kannauj. The growers put up their problems of potato cultivation before the scientists through telecouselling mode of distance training as and when required. The scientists solved their problems immediately with same mode of distance training. The cultivation of potato was recommended with three varieties i.e. Kufri Bahar, Kufri Pukhraj and Kufri Pushkar through telecounselling mode. Cultivars Kufri Bahar, Kufri Pukhraj and Kufri Pushkar gave tuber yield by 331.55 q/ha, 354.22 q/ha and 383.71 q/ha, respectively. The growth and yield traits were concordant to yield obtained from potato cultivars. The highest net return Rs. 123569/ha and BCR 1:2.15 were obtained from adoption of cultivation of cultivar Kufri Pushkar closely followed by the net return Rs. 106031/ha and BCR 1:2.00 available from the cultivation of Kufri Pukhraj.

How to cite this article : Singh, R.A., Singh, Amar, Yadav, Dharmendra, Singh, Jitendra and Pal, S.B. (2016). Potato production through telecounselling mode of extension education. Agric. Update, 11(4): 423-426; DOI : 10.15740/HAS/AU/11.4/423-426.
Author for correspondence :

\section{R.A. SINGH}

C.S. Azad University of Agriculture and

Technology, KANPUR (U.P.) INDIA

Email: rasinghcsau@ gmail.com

See end of the article for authors' affiliations 